\title{
Wokół gdańskiego afisza teatralnego z XVIII wieku
}

Piotr Kąkol 


\section{Piotr Kąkol}

\section{Wokół gdańskiego afisza teatralnego z XVIII wieku}

$\mathrm{G}$ dańsk wpisał się w historii polskiego afisza teatralnego szczególną kartą. To z dziejów kolegium jezuickiego działającego na przedmieściu nadbałtyckiego grodu, w Starych Szkotach, badacze wydobyli najwcześniejszą, bo z roku 1618, wiadomość o druku zapraszającym na przedstawienie. W tym bowiem czasie władze Gdańska zabroniły braciom zakonnym „rozwieszania w mieście afiszów i bicia w bęben, którymi to sposobami zawiadamiali oni mieszkańców o mającym się odbyć w kolegium spektaklu"1. Ta często powtarzana informacja $^{2}$ nie stała się jednak powodem do szerszego zainteresowania się zachowanymi zbiorami gdańskich afiszów teatralnych — między innymi afiszów z XVIII wieku.

Owszem, wykorzystywano już w przeszłości pojedyncze druki. Próbowano na przykład przypisywać je odpowiednim zespołom, ustalać daty pochodzenia, stawały się również cennym źródłem do opracowania historii gdańskiej sceny. Główną uwagę skupiano jednak na nielicznych i to najstarszych wydaniach. Przedruków i omówienia doczekał się na przykład bodaj najwcześniejszy z zachowanych do dziś afiszów gdańskich, afisz zespołu Cathariny Elisabeth Velten z 1695 roku $^{3}$. Kolejne znane druki pochodzą już z następnego stulecia. Niektóre z nich zostały opublikowane i zaopatrzone w krytyczne uwagi badaczy, jak chociażby afisz z ok. 1730 anonsujący sztukę Die in Marmor eingegrabene Tugend und Beständigkeit einer

\footnotetext{
1 T. Witczak, Teatr i dramat staropolski w Gdańsku. (Przeglqd historycznomateriatowy), Gdańsk 1959, s. 119.

${ }^{2}$ Por.: J. Bolte, Das Danziger Theater im 16. und 17. Jahrhundert, Hamburg und Leipzig 1895, s. 51; P.Simson, Geschichte der Stadt Danzig, Bd. II, Danzig 1918, s. 548; J. Lipiński, O afiszach, reklamie i krytyce, „Pamiętnik Teatralny" 1962, z. 1, s. 45; Polski afisz teatralny 1765-1939, wst. i wybór afiszów E. Makomaska, opr. edyt. i typogr. M. Sztuka, Warszawa 1974, s. 2; Z. Raszewski, Warszawski afisz dzienny. Teatr Narodowy i jego kontynuacje (1765-1915), „Pamiętnik Teatralny” 1987, z. 4, s. 492.

${ }^{3}$ Egz. Biblioteki Gdańskiej Polskiej Akademii Nauk (dalej: BG PAN), sygn. Od $214998^{\circ}$. Por.: A. Mundt, Ein alter Danziger Komödienzettel, „Altpreußische Monatsschrift” 1867, Bd. 4, s. 380-381, 677; J. Bolte, op. cit., s. 143-144.
} 
Dame, Oder: Der die Ehr und Freundschafft hochschätzende Cavallier ${ }^{4}$ lub obszerny pod względem treściowym afisz z 1733 roku $^{5}$. Podobnych przykładów odnajdujemy w gdańskiej prasie czy w pracach dotyczących historii nadmotławskiej sceny i literatury jeszcze kilka ${ }^{6}$. Jednak brak spojrzenia na cały zbiór prowadził niejednokrotnie do wysunięcia wniosków, które mogą obecnie budzić wątpliwości. Należy natomiast przyznać, że odpowiednie wykorzystanie przechowywanych w Bibliotece Gdańskiej Polskiej Akademii Nauk pod jedną sygnaturą ${ }^{7}$ około siedmiuset wydań gdańskich afiszów teatralnych z XVIII wieku, stanowiących obecnie materiał źródłowy szerszych badań, może sprawiać trudności. Dla porównania warto dodać, że krakowskich anonsów z lat 1781-1830 w zbiorach ogólnodostępnych — jak ustalił Maciej Szeleta - jest tylko czterdzieści jeden ${ }^{8}$. Kłopoty z tą bazą materiałową nie wynikają jednak z jej obszerności, ale z samego jej uporządkowania, a raczej jego braku, który należy przypisać niewydrukowanym na afiszach datom anonsowanych przedstawien, kłopotom $z$ ich ustaleniem oraz dotychczasowym skromnym badaniom nad teatrem gdańskim w XVIII wieku.

\footnotetext{
${ }^{4}$ Egz. BG PAN, sygn. Od $215068^{\circ}$; por. „Danziger Bürger-Zeitung” 1905, nr 27, s. 5; O. Günther, Ein Danziger Theaterzettel von 1730, „Mitteilungen des Westpreußischen Geschichtsvereins” Jg. 4, 1905, s. 59-61.

${ }^{5}$. Afisz ten znany jest obecnie tylko z przedruku, a zapowiadał on na 16 listopada 1733 roku trzy utwory: muzyczny prolog Die wiederhergestellte güldne Zeit, wczesnooświeceniową sztukę P. Metastasia Il Siroe (na afiszu pt. Der großmüthige Sirö, oder: Die triumphirende Gerechtigkeit und vom Himmel beschiitzte Unschuld) - stanowiąca w przedstawieniu główny punkt programu — oraz komedię Moliera Les précieuses ridicules (Die kostbahren Lächerlichkeiten). Dodatkową atrakcją przedstawienia bylo komiczne intermedium, z typowymi dla komedii dell'arte postaciami: Arlekinem i Murmelią. Por. Danziger Theaterzettel aus der 1. Hälfte des 18. Jahrhunderts, „Der Artushof" 1880, nr 3, s. 23-24; J. Bolte, op. cit., s. 164, 166-168; „Danziger Zeitung” 1920, nr 558.

${ }^{6} \mathrm{~Np}$. treść dwóch nieistniejących dziś w oryginale afiszów z 1771 roku odnajdujemy w czasopismach z XIX wieku (por. Beitrag zum theatralischen Archive, „Danziger Dampfboot” 1836, nr 70, s. 342; E. Garbe, Vor hundert Jahren, „Der Artushof” 1880, nr 1, s. 6-7). Setna rocznica (błędna zresztą) gdańskiej premiery Zbójców Schillera była dobrą okazją dla przypomnienia premierowego afisza (E. Leidig, Zwei Jubiläen, „Danziger Zeitung” 1885, nr 15524). Natomiast P.Gerlach (Goethe und Danzig, Danzig 1935, s. 12) nie omieszkał wykorzystać w swojej pracy fragmentu afisza z 1778 roku zapowiadającego sceniczną adaptację powieści Goethego Cierpienia mtodego Wertera. Z kolei E. A. Hagen w swej monumentalnej rozprawie Geschichte des Theaters in Prenßen, vornämlich der Bühnen in Königsberg und Danzig von ihren ersten Anfägen bis zu den Gastspielen J. Fischer's und L. Devrient's (Königsberg 1854) oprócz wykorzystania afiszów do ustalenia repertuaru czy obsady przytacza treść trzech nadmotlawskich anonsów teatralnych (s. 284-288). Podobnie uczynił, choć ograniczył się do jednego afisza z 1771 roku, O. Rub, Die dramatische Kunst in Danzig von 1615 bis 1893, Danzig 1894, s. 29-30, przypis *).

${ }^{7}$ BG PAN, sygn. Od $214802^{\circ}$. Znane są również inne zbiory czy pojedyncze druki gdańskich afiszów. Poza wskazanymi wyżej drukami można wymienić tu zbiór afiszów z końca XVIII wieku (36 wydań) przechowywany w Archiwum Państwowym w Gdańsku (dalej: AP Gd.), sygn. 300, 36/71. Nadmotławskie teatralia znalazły się także w Österreichische Nationalbibliothek (por. J. R. Hänsel, Die Geschichte des Theaterzettels und seine Wirkung in der Öffentlichkeit, Berlin 1962, s. 187-188). Dr Barbara Lesák i Peter Oliver Loew, któremu jestem winny w tym miejscu podziękowanie za wskazanie kilku artykułów w dziewiętnastowiecznej prasie gdańskiej i wytrwałe zdobywanie dla mnie fachowej literatury, odszukali w Österreichisches Theatermuseum nadmotławski afisz z 23 października 1771 roku (ten sam, o którym pisał J. R. Hänsel) i przesłali mi jego kopię, co odnotowuję z wdzięcznością. Afisz ten zapowiadał dwie sztuki: Die Familie auf dem Lande F. S. Hensel oraz Der faule Bauer. W niniejszym artykule uwagę skupiono głównie na pierwszym z wymienionych zbiorów, który jest najbogatszą ilościowo i najróżnorodniejszą kolekcją gdańskich afiszów z XVIII stulecia.

${ }^{8}$ Zob. M. Szeleta, Krakowski afisz teatralny 1781-1893, „Pamiętnik Teatralny” 1996, nr 3-4, s. 248-249.
} 
Bogactwa gdańskiego zbioru nie określa tylko liczba wydań afiszów, ale także różnorodność prezentowanych przez nie zespołów teatralnych i czas, z którego pochodzą. To tutaj znajdują się cztery anonse zapowiadające gdańskie występy zespołu Agnieszki i Tomasza Truskolaskich z 1797 roku, które odkrył i opisał Zbigniew Raszewski ${ }^{9}$. Jeśli sięgniemy po zbiór z początku XIX wieku, to znajdziemy afisze z gościnnych występów w 1804 roku zespołu baletowego Le Deux czy zespołu Wojciecha Bogusławskiego z 1811 roku $^{10}$. Dotarcie do nich jest jednak sprawą prostą, każdy znajduje się na swoim miejscu w układzie chrono$\operatorname{logicznym}^{11}$. Inaczej rzecz przedstawia się z większością druków osiemnastowiecznych.

Już z zapisu w przedwojennym katalogu dowiadujemy się, że są to afisze wydawane od 1771 roku. Podana data to oczywiście czas rozpoczęcia nad Motławą imprezy teatralnej przez Joannę Karolinę Schụch i Józefa Feliksa von Kurza — słynnego Bernardona, późniejszego dyrektora teatru w Warszawie. Wskazanego roku nie zapisano zapewne tutaj przypadkowo, ponieważ jest on wydrukowany na najstarszym afiszu zawierającym pełną datę zapowiadanego przedstawienia, tj. dzień, miesiąc, rok. Należy on również do tej grupy nielicznych, które podają datę, a jest ich w całym prawie siedmiusetegzemplarzowym zbiorze zaledwie sześćdziesiąt. Pozostałe nie tylko nie informują o dniu przedstawienia, ale również o roku, co najwyżej podają określenie „heute”. Kolejnym utrudnieniem w poruszaniu się po zbiorze jest ułożenie ponad czterystu afiszów w poszytach, stanowiących rzekomo roczniki, lecz już wstępne badania wykazały, że te anonse teatralne zszyto w sposób przypadkowy. Nieznany dziś twórca zbioru — działając zapewne w dobrej wierze - bezkrytycznie oparł się na ręcznie zapisanych na afiszach datach. Gdański zespól afiszów wymaga zatem nowego dokonania podziałów. Staje się to jednakże niemożliwe bez wykorzystania dotychczasowych badań nad osiemnastowiecznym teatrem gdańskim, zbadania dodatkowych źródeł archiwalnych, ówczesnej prasy gdańskiej i obcej (głównie z obszaru niemieckojęzycznego), krytyki teatralnej. Dopiero w świetle tak szeroko zakrojonych badań afisz z XVIII wieku staje się lekturą przynoszącą tyle nowych rozwiązań, co nowych pytań dotyczących tych druków, jak i nadmotławskiej sceny. Afisz zaczął zatem żyć nie tylko jako dokument odpowiadający na pytania: co? gdzie? kiedy?, choć to pytania zasadnicze, ale jako świadectwo dawnych obyczajów, mód, którym on także podlegał.

Zbigniew Raszewski w swojej pracy poświęconej afiszom warszawskim uznał zaproszenie za najważniejszą funkcję afisza ${ }^{12}$. Odpowiadając sobie zatem na pytanie: „Kto zaprasza do teatru?" uzyskał on podział druków stołecznych na grupy, typy i odmiany mieszczące się w określonych przedziałach czasowych; podobnie uczynił z anonsami krakowskimi Maciej

\footnotetext{
${ }^{9}$ Zob. Z. Raszewski, Z tradycji teatralnych Pomorza, Wielkopolski i Ślaska, Wrocław 1955, s. 70-73.

${ }^{10}$ Por. Z. Ciesielski, A. Świderska, Teatr Boguslawskiego w Gdańsku. Odszukane afisze baletu (1804) i zespołu dramatycznego (1811), „Pamiętnik Teatralny” 1967, z. 3-4, s. 458-462.

"Afisze te znajdują się, podobnie jak druki osiemnastowieczne, pod tą samą sygnaturą bibliotecznego zbioru, lecz $w$ poszytach $z$ odpowiednim oznaczeniem roku wydania.

12 Zob. Z. Raszewski, Warszawski afisz. .., op. cit.
} 
Szeleta $^{13}$. Nie zapomnijmy jednak, że afisze, którymi ci badacze dysponowali, były datowane i to dość dokładnie. Inną oczywiście rzeczą, iż stan badań nad warszawskim i krakowskim teatrem przedstawia się znacznie lepiej niż nad gdańskim. Nadal jesteśmy tu zdani na niewolne od błędów i przestarzałe metodologicznie prace Ernsta Augusta Hagena z polowy XIX wieku ${ }^{14}$ i Otto Ruba $z$ końca tegoż stulecia ${ }^{15}$. Niemniej zaproponowane powyżej kryterium wskazania zapraszającego, tzn. nazwy zespołu, instytucji lub siedziby, staje się przydatne w chronologicznym uporządkowaniu afiszów z nadbałtyckiego zbioru. Tu należy uczynić jeszcze jedno spostrzeżenie: nie zawsze da się go wyróżnić na podstawie gdańskiego anonsu teatralnego. Nie możemy zatem uznać podpisu zapraszającego jako elementu stałego, czyli takiego, który w przypadku warszawskich i krakowskich druków — podobnie jak tytuł sztuki, data przedstawienia wraz z godziną rozpoczęcia spektaklu oraz wykaz cen - został uznany za najstarszy i najtrwalszy. W przypadku nadmotławskich afiszów możemy wyróżnić dwie stałe rubryki, czyli tytuł (tytuły) sztuki i godzinę rozpoczęcia widowiska.

Podpisu zapraszającego nie mają dwa afisze, bodaj najstarsze w omawianym zbiorze. Ich podobieństwo typograficzne oraz podobieństwo treści nagłówka ${ }^{16}$, rubryki podającej miejsce przedstawienia i cennik ${ }^{17}$ wskazuje na pochodzenie $z$ czasów jednej antrepryzy. Żaden inny $\mathrm{z}$ zachowanych afiszów nie jest do nich podobny pod względem wymienionych informacji i układu graficznego ${ }^{18}$. Pierwszy z nich anonsował popularną w XVIII wieku komedię Johanna Christiana Krügera Der blinde Ehemann, oder: Die tugendhafte Frau, wystawioną po raz pierwszy w Hamburgu w 1747 roku ${ }^{19}$ oraz nieznaną z tytułu jednoaktówkę (lustiges Nachspiel). Ponadto utwór Krügera miano zakończyć muzycznym divertissement ${ }^{20}$. Drugi afisz zapowiadał sztukę pt. Der Poetische Dorf-Junker Destouchesa, prawdopodobnie w przekładzie pochodzącej z Gdańska Luizy Adelgundy Gottsched — żony lipskiego profesora, oraz utwór

\footnotetext{
${ }_{13}$ Zob. M. Szeleta, op. cit.

${ }^{14}$ Zob. E. A. Hagen, op. cit.

15 Zob. O. Rub, op. cit.

${ }^{16}$ „Mit Bewilligung einer hohen Obrigkeit / wird heute / auf der hiesigen / Schaubühne / (...)".

17 „Der Schuplatz ist in dem bekannten Comödienhause, wo ehedessen die Fechtschule gestanden. / Die Person zahlet in der Loge 2 Tympf, par Terre 1 Gulden, auf den andern / Platz 18 Groschen, aufden dritten Platz 12 Groschen, und / auf den letzten Platz 6 Groschen".
}

${ }^{18} \mathrm{Z}$ tymi afiszami należałoby prawdopodobnie wiązać afisz znany jedynie $\mathrm{z}$ treści, a opublikowany między innymi przez J. Boltego (op. cit., s. 164-166). Dziś możemy wskazać podobieństwo treściowe między nimi (podobnie brzmi nagłówek, informacja o miejscu spektaklu i cennik), a nie typograficzne. Anons ten zapowiadal dwa utwory: Das affectirte Frauenzimmer oder Die Männer-liebende Rosette mit Arlequin einem lächerlichem Pilgram oraz Der plauderhafte Schäfer. Samo przedstawienie Bolte datuje na początek lat trzydziestych.

19 Zob. J. Ch. Krüger, Poetische und Theatralische Schriften, Hrsg. J. F. Löwen, Leipzig 1763, s. 213-290. Egz. BG PAN, sygn. De $62508^{\circ}$.

${ }^{20}$ Treść tego afisza opublikował już E. A. Hagen (op. cit., s. 286-287). Ponadto podal (s. 286, przyp. ${ }^{\star}$ ) przybliżoną datę jego pochodzenia: październik 1771 rok, co wydaje się (podobnie jak całe uzasadnienie) absurdalne, ponieważ wówczas działała nad Motławą Joanna Karolina Schuch ze swoim zespołem. Natomiast zachowany materiał źródłowy pozwala stwierdzić, że na afiszach z początku lat'siedemdziesiątych podawano już nazwę zapraszającego. 
zatytułowany Scapin der Haußknecht holenderskiego autora, niejakiego St. Leeuwa ${ }^{21}$. Afisz zawiadamiał widzów jeszcze o dodatkowych atrakcjach: śpiewaczka miała wykonać kilka arii, zaś najmłodsza panna Creutzerin popisać się kilkoma solowymi tańcami.

Daty anonsowanych przez te druki przedstawień stanowią do dziś zagadkę. Wskazane na jednym $z$ nich nazwisko młodej tancerki może jednak narzucać spostrzeżenie, iż afisze te pochodzą z przełomu lat czterdziestych i pięćdziesiątych (tylko z jednej strony czas ograniczony jest przez datę prapremiery komedii Krügera), czyli z lat działalności impresaryjnej gdańskiego złotnika Jana Karola Dietricha, który co prawda sam nie występował na scenie, ale sprowadzał uznane zespoły i aktorów z głębi Niemiec. Jednej z takich grup przewodniczyła „Prinzipalin” Kreutzer ${ }^{22}$. Czy i w jaki sposób należy łączyć te dwie osoby, tj. młodą tancerkę i pryncypałową z Marią Magdaleną Creutzerin, która podpisała się pod supliką skierowaną do Rady Miasta w grudniu 1737 roku $^{23}$, dotychczas nie wyjaśniono. Samo podobieństwo nazwisk może jest tu najzupełniej przypadkowe.

Kolejny chronologicznie afisz jest świadectwem obecności nad Motławą zespołu Konrada Ernesta Ackermanna (Ackermannische Gesellschaft deutscher Schauspieler). Zapowiadał on odegranie 18 października 1756 roku ${ }^{24}$ dwóch utworów: komedii Ludwiga Holberga Der geschäftige Müssiggänger oraz pantomimicznego baletu Johanna Josepha von Bruniana Der großmüthige Wilde $^{25}$.

Pojedynczych czy też po kilka afiszów innych zespołów jest w omawianym zbiorze dziewięć:

- dwa afisze z 1782 roku (26 i 30 sierpnia), gdzie zapraszającym jest zespół włoski „Italienischen Sängern” (1. afisz) lub „Gesellschaft Italienischer Operisten” (2. afisz). Są to anonse z gościnnych występów „aufder Schuchischen Schaubühne” w Gdańsku włoskich śpiewaków operowych, wśród których znaleźli się: Rosa Scanavini, jej córka -

\footnotetext{
${ }^{21}$ Utwór ten był grywany także przez zespół Konrada Ernesta Ackermanna. Por. H. Eichhorn, Konrad Ernst Ackermann. Ein deutscher Theaterprinzipal, Emsdetten 1965, s. 268.

${ }^{22}$ Por.: Noch etwas aus Eckhofs Brieftasche, „Theater-Journal fuir Deutschland” 1781, 17. Stück, s. 92-93. Egz. Książnicy Pomorskiej w Szczecinie, sygn. 16343/10. XVIII; E. A. Hagen, op. cit., s. 121; O. Rub, op. cit., 9; T. Witczak, op. cit., s. 114-115; K. Wierzbicka-Michalska, Teatr warszawski za Sasów, Wrocław 1964, s. 121; K. Wierzbicka-Michalska, Aktorzy cudzoziemscy w Warszawie w XVIII wieku, Wrocław 1975, s. 26.

${ }^{23}$ AP Gd., sygn. 300, 36/70, s. 35-38; por. AP Gd., sygn. 300, 12/148, s. 67; M. Foltz, Geschichte des Danziger Stadthaushalts, Danzig 1912, s. 211.

${ }^{24}$ Poza dniem i miesiącem data roczna nie została wydrukowana na afiszu. Do podania takiej daty rocznej upoważnia nas zachowany w rękopisie gdański repertuar tegoż zespołu z 1755 roku i brak w owym spisie zapowiadanego afiszem przedstawienia (egz. BG PAN, sygn. Ms 525, k. 74 v. -76v.). Zgodnie ze stanem badań obecność nad Motławą trupy Ackermanna odnotowujemy jeszcze tylko w 1756 roku. Zestawienie repertuarowe (w ukladzie chronologicznym) z poprzedniego sezonu - nieznane Herbertowi Eichhornowi (op. cit., s. 228) - sporządził Beniamin Benedykt Henrichsdorff, członek gdańskiego towarzystwa znanego pod kilkoma nazwami: Aestetische Gesellschaft zu Danzig, Vereinigte Gesellschaft zur Übung der schönen Wissenschaften in Danzig oraz Gesellschaft zur Beförderung des guten Geschmacks (por. E. Kotarski, Gdańska poezja okolicznośiowa XVIII wieku, Gdańsk 1997, s. 43).

${ }^{25}$ Por. H. Eichhorn, op. cit., s. 198-199.
} 
Celestina, Domenico Tonioli oraz pan Cesari. Od czasu nadmotławskich przedstawień datuje się ich karierę na terenie Polski, między innymi w Warszawie i w Krakowie ${ }^{26}$;

- dwa afisze teatru marionetek; zapraszającym jest „kleine Marionetten-Gesellschaft”;

— cztery afisze z sierpnia 1797 roku; zapraszający: „D[yrektor] T[eatru] Truskolaski z swoją Kompanią” (druga strona zredagowana w języku niemieckim donosi: „Herr Schauspiel-Director Truskolaski aus Warschau mit seiner bey sich habenden Gesellschaft pollnischer Schauspieler") ${ }^{27}$;

— jeden afisz z czerwca 1798 roku; zapraszający: „Balletmeister Weininger mit seinen Kindern" 28 .

Z tego zestawu — niekompletnego, bo brakuje tutaj afiszów zespołu Schuchów, o czym później - na uwagę zasługują gdańskie afisze teatru lalek. Jest to znalezisko na tyle cenne, na ile uświadomimy sobie fakt, że w literaturze przedmiotu mówiono do tej pory przynajmniej do 1990 roku, kiedy to ukazała się praca Marka Waszkiela - o odkryciu tylko czterech afiszów tego typu teatru z terenów Polski sprzed XX wieku (jeden siedemnastowieczny?, jeden z XVIII i dwa z XIX wieku) ${ }^{29}$. Na gdańskich afiszach brak nie tylko dat przedstawień, ale również nazwiska marionetkarza, o którym wiemy z owych druków tylko tyle, iż mieszkał w Gdańsku w zajeździe „Pod Czarnym Orłem” (im schwarzen Adler) niedaleko kościoła dominikanów pod wezwaniem św. Mikołaja (Schwarz-München). U niego można było również nabyć bilety na przedstawienia. Jedynie dzięki szczęśliwemu zbiegowi okoliczności możemy dziś powiedzieć, że nadmotławskie przedstawienia zorganizował, znany ze swej działalności lalkarskiej w Pradze, na Śląsku, w Warszawie i w Krakowie, Gerhard Bressler ${ }^{30}$. Zachowany do dzisiaj - często też publikowany - warszawski afisz jego teatru z 1792 roku zapowiadał ten sam utwór, co i w Gdańsku. Była to komedia pt. Ardeo, czyli Chroniący się niewiasty zwątlony niewolnik, albo mocq Kupidyna uszczęstiwiony strzelec ${ }^{31}$.

\footnotetext{
${ }^{26}$ Por.: K. Wierzbicka-Michalska, Aktorzy..., op. cit., s. 157-173; Z. Jabłoński, Teatr $w$ Krakowie $w$ latach 1773-1795, w: Teatr polski od schylku XVIII wieku do roku 1863. Lata 1773-1830, Warszawa 1993, s. 26-31 (Dzieje teatru polskiego, t. 2, cz. 1); A. Zórawska-Witkowska, Muzyka na dworze i w teatrze Stanistawa Augusta, Warszawa 1995 , s. 126-135.

${ }^{27}$ Zbigniew Raszewski ( $Z$ tradycji..., op. cit., s. 70-73) nie znalazł źródła, które podawałoby czas pobytu w Gdańsku zespołu Truskolaskich. Obecnie możemy wskazać, że trupa przyjechała nad Motławę z Poznania 8 sierpnia, natomiast wyjazd Truskolaskiego do Kwidzyna (nadal nie wiemy, czy towarzyszył mu cały zespół) nastapił 31 sierpnia 1797 roku („Danziger Nachrichten und Anzeigen” 1797, nr 64, s. 569; nr 71, s. 635. Egz. BG PAN, sygn. X $\left.3518^{\circ}\right)$.

${ }^{28} \mathrm{Na}$ afiszu zapisano ręcznie rok 1800 , co w świetle wydrukowanej daty dziennej: ,heute Sontag den 3ten Junii" oraz ogłoszeń prasowych („Danziger Nachrichten und Anzeigen” 1798, nr 42, s. 454; nr 43, s. 464. Egz. BG PAN, sygn. X $3518^{\circ}$ ) jest ewidentna pomylka. Weininger w latach 1783-1787(?) był baletmistrzem w zespole prowadzonym przez Joannę Karolinę Schuch. Później na własną rękę podjął się działalności teatralnej.

${ }^{29}$ Zob. M. Waszkiel, Dzieje teatru lalek w Polsce (do 1945 roku), Warszawa 1990, s. 16, przyp. 19.

${ }^{30}$ Por. : L. Bernacki, Teatr, dramat i muzyka za Stanislawa Augusta, t. 1, Lwów 1925, s. 200, 362; J. Jackl, Widowiska popularne $w$ Warszawie $w$ latach 1764-1794. Kronika, „Pamiętnik Teatralny” 1968, z. 1, s. 86, 94-95; Z. Jabłoński, Dzieje teatru $w$ Krakowie $w$ latach 1781-1830, Kraków 1980, s. 74 (Dzieje teatru w Krakowie, t. 2); M. Waszkiel, op. cit., s. 81-84.

${ }^{31}$ Ardeo, Ein das Frauenzimmer fliehender, und doch wankelbarer Sclave der Liebe, oder: Der durch die Macht des Cupido
} 
Oba afisze — gdański i stołeczny — podają w sześciu punktach przemiany laiki, zwanej Pimperle, odtwarzającej postać Ardeusza. Przedstawiał on:

1-mo. Wesołego hajczaka. [Einen lustigen Forstbedienten].

2-do. Na wzór Platona gniewliwego udający Kolumbiny kochanka. [Einen verdrießlichen Liebhaber der Columbine].

3-tio. Mocą Kupidyna miłości niewolnika. [Von Cupido gefesselten Sclaven der Licbe].

4-to. Prześladowaniem oszukanego strzelca. [Verfolgten betrogenen Jäger].

5-to. Wesolego grzybów zbieracza. [Lustigen Schwamm-oder Pilzsucher].

6-to. Śmiesznie bojaźliwego jeźdźca. [Furchtsamen und lächerlich zu Pferde reitenden Bedienten] ${ }^{32}$.

Podobnie jak warszawskie przedstawienie komedii, tak i gdańskie miało zostać urozmaicone pokazami lalek trickowych:

1-mo. Dwóch mężów na kamieniu leżących odmieniają się w sztucznej wody fontannę, a na koniec w starą wieżę. [Aufeinen Stein liegende zwey Männer, verändern sich in eine Wasserkunst, und gleich wieder in einen alten Thurm].

2-do. Drzewo przemienia się w Kupidyna. [Ein Baum verwandelt sich in Cupido].

3-tio. Grzyb sztucznie odmienia się w kominiarza. [Ein Pilz verwandelt sich auf eine künstliche Art in einen lebendigen Rauchfangkehrer].

4-to. Skała duża, na której się owce pasą, odmienia się w siedmiogłowe monstrum, z którego na koniec zrobi się wieża zdezelowana. [Ein grosser Felsen, worauf Schaafe weiden, verändern sich in ein siebenköpfiges Ungeheuer, und selbiges wieder in einen alten eingefallen Thurm].

O ile w Gdańsku zapowiedziano tylko jeden utwór, o tyle w Warszawie nie poprzestano na nim. Po Ardeo miano jeszcze wystawić tego samego dnia (16 lipca) komiczną operę i komedię „ekstrakomiczną” w jednym akcie Śmierć zaptaci wszystko.

Drugi z zachowanych afiszów gdańskich ponownie anonsował występy z użyciem lalki Pimperle. Była to komedia pod nieco długim tytułem Die List der Weiber, oder: Männer List ist behend; Weiber List hat gar kein End. Sonst genannt [tzn. komedia - P. K. ]: Der scharfsichtige, argwohnische, zankende, raufende, und doch am Narrenseil herumgezogene alte Anselmo mit Lucinda und Helmundi, Zweyer Erzfeinde des alten Anselmo und verschmitzte Unterhändler in Liebessachen. Sugerowana tu przez tytuł treść utworu została nieznacznie poszerzona przez wierszowany komentarz zamieszczony na afiszu. Podkreślono w nim jedynie atrakcyjność efektów komicznych, których dostarczycielem w przedstawieniu był Pimperle. Całość zamknięto jed-

glücklich gewordene Jäger. Polskie tłumaczenie niemieckiego tytułu z gdańskiego afısza podano za warszawskim afiszem zredagowanym $w$ dwu językach: polskim i niemieckim. Podobnie uczyniono z innymi częściami treści tego anonsu.

${ }^{32} \mathrm{~W}$ nawiasach kwadratowych, tu i poniżej, podano treść za gdańskim afiszem. Rozbieżności w tlumaczeniu, jak widać, są nieznaczne. 
nak stwierdzeniem mającym wzbudzić ciekawość czytelników afisza i zachęcić ich do odwiedzenia teatru:

Doch weil dies Blat zu klein, will man von mehrern schweigen.

Des Pimperles Lustbarkeit wird alles besser zeigen.

Próba odpowiedzi na pytanie o czas występów marionetkarza w Gdańsku nie przyniosła dotychczas jednoznacznych rozstrzygnięć. Sama treść i typografia nadmotławskich afiszów wskazuje na lata osiemdziesiąte XVIII stulecia ${ }^{33}$. Przypomnijmy nadto, iż działalność Bresslera została poświadczona w kilku miejscach: w 1775 roku występował w Pradze, o zezwolenie na występy w Czeskim Cieszynie i na Śląsku starał się w latach 1777-1778, prawdopodobnie to on otrzymał w Warszawie od Stanisława Augusta 25 dukatów w 1781 roku, później — w 1787 - grał w Krakowie, a w 1792 ponownie zjawił się w stolicy Polski ${ }^{34}$. Najprawdopodobniejszą datą pochodzenia gdańskich afiszów jest rok 1783. Wówczas — dokładniej: 11 sierpnia - nieznany z nazwiska marionetkarz wniósł do kasy miejskiej opłatę w wysokości 120 florenów ${ }^{35}$. Być może owym płatnikiem był Gerhard Bressler.

Pora w końcu na prezentację najobszerniejszej części zbioru gdańskich afiszów, czyli około sześciuset pięćdziesięciu anonsów związanych z zespołem Schuchów, którzy przez ponad pół wieku decydowali o wizerunku gdańskiego teatru. Z tym nazwiskiem większość gdańszczan zapoznała się w lipcu 1757 roku, gdy po raz pierwszy założyciel i dyrektor trupy teatralnej Franciszek Schuch Starszy przybył nad Motławę wraz ze swoją trupą ${ }^{36}$. Niestety, z pobytu Schucha nad Motławą nie zachował się w omawianym zbiorze żaden afisz, choć wiemy $z$ ogłoszeń prasowych, że taką formę zapowiadania przedstawień stosowal ${ }^{37}$. Nie dysponujemy również afiszami trupy jego syna, także Franciszka, który po śmierci ojca przejął zespół i występował tu w latach 1764-1767. Działalność teatralną Schucha Młodszego wspie-

${ }^{33}$ Dwie rzeczy wskazywałyby na to, ze przedstawienia odbyły się przed 1793 rokiem: brak na afiszu orła pruskiego (miały go prawie wszystkie zachowane do dziś gdańskie afisze teatralne anonsujące przedstawienia po włączeniu Gdańska do Prus; brakuje go jednak na przykład na afiszach zespołu Agnieszki i Tomasza Truskolaskich z 1797 roku) oraz podane jednostki monetarne. Przy wykazie cen za miejsca od 1793 roku na afiszach rozróżniano monety pruskie i gdańskie. W gdańskich anonsach Bresslera nie uwzględniono tego podziału.

${ }^{34}$ Por. przyp. 30.

${ }^{35}$ AP Gd., sygn. $300,12 / 190$, s. 82.

${ }^{36}$ "Gemeinnützige Danziger Anzeigen, Erfahrungen und Erläuterungen allerley niitzlicher Dinge und Seltenheiten" 1757, nr 29, s. 140. Egz. BG PAN, sygn. X $3518^{\circ}$; Critische Nachricht von der Schuchischen Schauspielergesellschaft, Danzig 1758. Egz. BG PAN, sygn. Od $215148^{\circ}$. Do Gdańska Schuch powracał jeszcze w 1759, 1762 i 1763 roku, co wynika $z$ wpisów do ksiąg gdańskiej Kamerarii potwierdzających wynajęcie budynku teatralnego (AP Gd., sygn. 300, 12/173, s. 62; 300, 12/176, s. 62; 300, 12/250, s. 174) oraz z ogłoszeń prasowych („Wöchentlichen Danziger Anzeigen und dienliche Nachrichten" 1759, nr 31, s. 151, 152; 1762, nr 31, s. 155, 157; 1763, nr 3, s. 15; nr 29, s. 153; nr 31, s. 169. Egz. BG PAN, sygn. X $\left.3518^{\circ}\right)$. Por. też: E. A. Hagen, op. cit., s. 242-261; K. Liss, Das Theater des alten Schuch. Geschichte und Betrachtung einer deutschen Wandertruppe des 18. Jahrhunderts, Berlin 1925 (mszps Deutsche Staatsbibliothek w Berlinie, sygn. Ms. 26. 271).

37 "Gemeinnützige Danziger Anzeigen, Erfahrungen und Erläuterungen allerley nützlicher Dinge und Seltenheiten” 1757, nr 29, s. 137. Egz. BG PAN, sygn. X $3518^{\circ}$. 
rała jego żona - Joanna Karolina. Od 1771 roku, najpierw przy współudziale Józefa Feliksa von Kurza ${ }^{38}$, później już samodzielnie zaczęła prowadzić zespół.

Zachowanym śladem jej działalności i współpracy z Kurzem nad Motławą - oprócz afiszów z innych zbiorów oraz znanych dziś jedynie z przedruku ${ }^{39}$ - jest afisz z 28 października 1771 roku, zapowiadający utwór pt. Die Insel der gesunden Vernunft oder Die doppelte Untreue autorstwa samego von Kurza 40 .

Gdy 4 grudnia 1771 roku zespół Karoliny Schuch i Józefa von Kurza opuszczał Gdańsk ${ }^{41}$, chyba nikt $z$ mieszkańców nadbałtyckiego grodu i nikt z członków trupy aktorskiej nie sądził, że przez kilka kolejnych lat kontakt z Melpomeną i Talią zostanie utrudniony przez pierwszy rozbiór Polski. Kolejna informacja o wizycie zespołu nad Motławą pochodzi dopiero z 1773 roku $^{42}$. Przedstawienia nie odbywały się już w teatrze znajdującym się $w$ obrębie wałów miasta, lecz w specjalnej budzie stojącej na terenie podmiejskiej osady — w Siedlcach (od 1772 roku zajętych przez wojska pruskie). W liście datowanym na 31 sierpnia 1774 roku angielski podróżnik Nathanael Wraxall donosił:

Most or all the suburbs, which are very populous and extensive, are already occupied by Prussian soldiery, who on one side are close to the very fortifications, a palisado only separating them from the Dantzic guards. Public diversions of every nature are prohibited by the magistrates, and the German comedy is in one of those suburbs which has been taken from them ${ }^{43}$.

${ }^{38}$ Karyna Wierzbicka-Michalska (Aktorzy..., op. cit., s. 202) błędnie utrzymuje, że spółka Kurz-Schuchowa rozpadta się na początku grudnia 1771, a słynny Bernardon - po wyjeździe Joanny Karoliny Schuch do Królewca - miał jakoby pozostać w Gdańsku do stycznia następnego roku, ponieważ „Ostatnia wzmianka o jego tam występach pochodzi z 9 stycznia 1772". Źródlem nieporozumienia stały się w tym wypadku recenzje teatralne, z których pochodzi owa „ostatnia wzmianka”, a uznane przez badaczkę — prawdopodobnie na podstawie miejsca drugiego wydania - za recenzje gdańskich przedstawień teatralnych. Tymczasem Ludwig Gomperz, bo on jest ich autorem, omówił w formie listów przedstawienia królewieckie. Por. [L. Gomperz], Billette der Madame F. und Madame R. über die Schuchische Schaubühne, Aufl. 2, Danzig 1775. Egz. BG PAN, sygn. Od $215248^{\circ}$.

${ }^{39}$ Por. przyp. 6 i 7.

${ }^{40}$ Treść tego afisza była publikowana już niejednokrotnie. Por.: E. A. Hagen, op. cit., s. 284-285; O. Rub, op. cit., s. 29-30, przyp. *); F. Raab, Johann Joseph Felix von Kurz genannt Bernardon, Frankfurt a/M. 1899, s. 179-181.

${ }^{41}$ "Wöchentlichen Danziger Anzeigen und dienliche Nachrichten" 1771, nr 49, s. 596. Egz. BG PAN, sygn. X 351 $8^{\circ}$. Sam Kurz wyjechał do Królewca, jak się zdaje, nieco wcześniej - 13 listopada. W ogłoszeniu prasowym poza nazwiskiem nie odnotowano profesji wyjeżdżającego, co z reguły było czynione („Wöchentlichen Danziger Anzeigen und dienliche Nachrichten" 1771, nr 46, s. 564. Egz. BG PAN, sygn. X $3518^{\circ}$ ).

${ }^{42}$ W ostatnim liście-recenzji z 26 maja 1773 roku ([L. Gomperz], op. cit., s. 118) czytamy: „Man sagt, die Gesellschaft gienge nach Danzig. (...) Bald reiset die Gesellschaft nach Tilsit, ein Ort wo nie eine gesittete Bühne war, und wird da beurtheilt (...)". Natomiast w sierpniu tego roku jeden z członków zespołu, pan Schilbach, oferował w Gdańsku swoje usługi jako nauczyciel tańca („Wöchentlichen Danziger Anzeigen und dienliche Nachrichten” 1773, nr 33, s. 422; nr 34, s. 438. Egz. BG PAN, sygn. X $3518^{\circ}$ ).

${ }^{43} \mathrm{~N}$. Wraxall, $A$ tour through some of The Northern Parts of Europe, particularly Copenhagen, Stockholm, and Petersburgh..., 2. ed. corr., London 1775, s. 346. Egz. BG PAN, sygn. Rb $9275^{2} 8^{\circ}$. 
Mimo starań u władz miasta ${ }^{44}$ Karolina Schuch była zmuszona grać tutaj aż do 1779 roku. $Z$ tego okresu zachowało się ponad sześćdziesiąt afiszów z wydrukowanymi datami, jeśli nie dziennymi, to przynajmniej rocznymi, oraz z podanym miejscem przedstawienia: „Der Schauplatz ist in der Schidlitz im weissen Pferde" ${ }^{\text {. }}$.

Rok 1779 był dla gdańskiego teatru okresem przełomowym. W czerwcu tegoż roku Karolina Schuch rozpoczęla wraz ze swoim zespołem występy w Siedlcach, czego dowodem jest osiem zachowanych afiszów ${ }^{46}$. Natomiast niecałe dwa miesiące później, 5 sierpnia, zainaugurowano działalność sceniczną w murach miasta ${ }^{47}$. I może nie byłoby w tym nic dziwnego, gdyby nie drobna informacja pojawiająca się na afiszach pochodzących z drugiej części sezonu. Osiemnaście anonsów z tego okresu informuje, że „Der Schauplatz ist in dem neu erbauten Comödien Hause". A to z kolei stawia pod znakiem zapytania dotychczasowe ustalenia, iż w obrębie wałów Gdańska do 1801 roku, czyli do otwarcia nowego teatru na Targu Węglowym, czynny był tylko jeden budynek teatralny — stara szkoła fechtunku przystosowana do potrzeb scenicznych na mocy uchwały Rady Miasta w $1730 \mathrm{roku}^{48}$. Same afisze zdają się potwierdzać takie przypuszczenie. Pochodzący z 1798 roku anons teatralny zespołu baletowego Weiningera podaje, że „Der Schauplatz ist im alten Comedienhause”, sugerując tym samym, iz przedstawienie odbywało się w dawnej szkole szermierczej, a nie w budynku wzniesionym w 1779 roku. Rzecz jednak wymaga bardziej gruntownych badań, by mogła zostać przyjęta jako pewnik. Na razie niech będzie to przykład, do jakich wniosków prowokuje afisz 49 .

Anonse $z$ informacją o nowym teatrze otwierają kolekcję około 600 wydań afiszów bez wydrukowanej daty zapowiadanych przedstawień. Kryterium ich podziału powinna tu stanowić nazwa zespołu zapraszającego na spektakl. Po śmierci Karoliny Schuch 8 listopada 1787 roku zespół aktorski zaczęły prowadzić jej dzieci: Fryderyka i Charlotta oraz syn z pierwszego małżeństwa Karol Steinberg. Zapraszającym na gdańskich afiszach od 1788 roku jest „Gesel-

${ }^{44}$ Por. P.Gerlach, op. cit., s. 13-14.

${ }^{45}$ „Zum weissen Pferd” to nazwa gospody, która znajdowala się na tej samej posesji w Siedlcach, co prowizoryczny, drewniany budynek teatralny poddany licytacji w 1780 roku („Wöchentlichen Danziger Anzeigen und dienliche Nachrichten" 1780, nr 34, s. 435; nr 35, s. 448; nr 36, s. 459. Egz. BG PAN, sygn. X $3518^{\circ}$ ).

${ }^{46} \mathrm{Na}$ afiszach tych widnieją tylko daty roczne. Dokladniejszych wiadomości z 1779 roku dostarcza nam jednak rękopiśmienne źródło - kronika Jan Karola Rubacha (egz. BG PAN, sygn. Ms 146, k. 181 v. -213 v.; egz. AP Gd., sygn. $300, \mathrm{R} / \mathrm{Bb}, 11$ c, k. 81 v. -106 v. ).

${ }^{47}$ BG PAN, sygn. Ms 146, k. 192; AP Gd., sygn. 300, R/Bb, 11c, k. 88 r. W jednym z berlińskich czasopism, w którym podano szczegółowy repertuar od 5 sierpnia do 26 listopada 1779 roku, czytamy: „Den 5 . [August - P. K. ] eröfnete Madam Schuch nach einer achtjährigen Abwesenheit ihre Bühne mit einem Prolog von Hrn Gomperz" (Nachrichten von den sämmtlichen Vorstellungen der Schuchischen Gesellschaft bey ihrem letztern Auffenthalt in Danzig, "Litteratur - und Theater-Zeitung” 1780, nr 2, s. 21. Egz. Biblioteki Uniwersyteckiej w Warszawie - dalej: BUW, sygn. 019151).

${ }^{48} \mathrm{Na}$ temat budynku teatralnego - dawnej szkoły fechtunku por. J. Limon, Gdański teatr „elżbietański”, Wroclaw 1989.

${ }^{49}$ Badania nad lokalizacją drugiego budynku teatralnego w Gdańsku prowadzi pan Jerzy Michalak, któremu w tym miejscu serdecznie dziękuję między innymi za wskazanie kilku źródeł archiwalnych. 
lschaft der Geschwister Schuch”, "Gesellschaft deutscher Schauspieler Gesellschaft der Geschwister Schuch”, „deutsche Schauspieler Gesellschaft der Geschwister Schuch” lub „Schauspieler Gesellschaft der Geschwister Schuch". Natomiast za dyrekcji Karoliny Schuch zapraszającym był zespół o nazwie "Schuchische Gesellschaft deutscher Schauspieler", "Schuchische Gesellschaft" lub „Schuchische Schauspieler Gesellschaft ${ }^{" 50}$. Tej prostej zasady podziału na dwie grupy nie dojrzal chyba twórca bibliotecznego zbioru, ponieważ w poszytach zawierających afisze $\mathrm{z}$ lat dziewięćdziesiątych, więc z czasu działalności rodzeństwa, znajdują się takie, których nagłówek podający nazwę zapraszającego wskazuje na pochodzenie sprzed 1788 . Są tutaj również anonse $z$ wpisanymi datami 1780 i 1795, gdy w rzeczywistości w tych latach gdańszczanie byli pozbawieni przyjemności kontaktu z Melpomeną i Talią. Wśród osiemnastowiecznych afiszów odnajdujemy i takie, które należy wiązać z początkiem następnego stulecia. W omawianym zbiorze znaleźć możemy także dwa anonse z Elbląga.

Zastanawiające jest, dlaczego na afiszach $z$ tego okresu nie podawano daty. Nic również nie wskazuje na to, że wpisywano ją wówczas ręcznie. Może ze względów ekonomicznych nie drukowano jej, aby móc wykorzystać niewyczerpany dotąd nakład przy nadarzającej się okazji powtórzenia spektaklu. Jeśli jednak spojrzeć na nieczęsto ukazujące się zestawy repertuarowe w czasopismach czy na recenzje lub omówienia sezonu, to uderza niewiarygodnie mała ilość powtórzeń całego przedstawienia, które składało się nierzadko z dwu, trzech utworów. Jeżeli już powtarzano jakąśs sztukę, to zazwyczaj w zestawieniu z inną. Gdański afisz był prawdopodobnie drukiem jednorazowego użytku, ukazującym się tego samego dnia, co zapowiadany spektakl. Ówcześni gdańszczanie zdawali sobie pewnie $z$ tego doskonale sprawę i nie potrzebowali dodatkowej informacji o dacie przedstawienia, wystarczyło najwyżej określenie „heute”. Gdyby poszukać dodatkowego potwierdzenia jednorazowości afisza, to nie sposób pominąć trzech różniących się pod względem typograficznym anonsów z 1782 roku zapowiadających Lanassę, utworu, który wystawiono wówczas czterokrotnie $^{51}$.

Jednocześnie afisz był zapewne programem, towarzyszącym widzowi w teatrze i chyba rozdawanym, nie sprzedawanym. Joanna Schopenhauer - matka filozofa, wspominając jeden z gdańskich koncertów w kościele, zanotowała:

Zasiedliśmy tedy w przepełnionej słuchaczami katedrze i przeglądali program, rozdawany przy wejściu jak przed świeckim koncertem lub komedią ${ }^{52}$.

Do domów dostarczali je roznosiciele ogłoszeń, rekrutujący się z gdańskiej biedoty, zatrudniani i skromnie wynagradzani przez bawiący w mieście zespól. Niekiedy ta grupa anonimowych ludzi uczestniczyła w przedstawieniach jako statyści. Dowiadujemy się o tym

\footnotetext{
${ }^{50}$ Pominięto tu zmieniającą się w różnych okresach formulę informującą o przywilejach otrzymanych przez zespól od króla pruskiego czy księcia kurlandzkiego, a którymi nigdy nie omieszkano się chwalić na afiszach. st Von der Schuchischen Gesellschaft, „Litteratur-und Theater-Zeitung” 1783, nr 3, s. 43. Egz. BUW, sygn. 019151. 52 J. Schopenhauer, Gdańskie wspomnienia mtodości, tł. i opr. T. Kruszyński, Wrocław 1959, s. 176.
} 
bowiem ze słów ich pieśni i utworów okolicznościowych, których kilka z przełomu XVIII i XIX wieku zachowało się do dzis ${ }^{53}$. Dodajmy, iż jedną z tych postaci uwiecznił gdański rytownik Mateusz Deisch ${ }^{54}$.

Brak wydrukowanej na gdańskich afiszach daty nie pozwala, w przeciwieństwie do warszawskich czy krakowskich anonsów, uznać tej rubryki za stałą. Do takich mogą tylko należeć tytuł zapowiadanej sztuki i godzina rozpoczęcia spektaklu. Pozostałe, to jest podpis zapraszającego, miejsce przedstawienia, cennik, autor (tłumacz, kompozytor, choreograf), obsada, komentarz, streszczenie oraz wiadomości porządkowe czy pojawiająca się na afiszach reklama handlowa należy uznać za zmienne elementy, czyli takie, które pojawiają się nieregularnie.

Uporządkowanie afiszów z gdańskiego zbioru ${ }^{55}$ pozwala na zaobserwowanie tendencji rozwojowych, zauważyć zmiany, jakie zachodziły w ciagu XVIII stulecia. Warto przyjrzeć się niektórym z nich, bo doprowadzą nas do kampanii przeprowadzonej pod koniec wieku na rzecz poprawy wizerunku afiszów teatralnych.

Komentarz był jedną z najbardziej eksploatowanych na afiszu rubryk i najbardziej różnorodna. $Z$ reguły łączył się z zachwalaniem utworu czy wykonania. Emilię Galotti Gottholda Ephraima Lessinga na afiszu z 1778 roku reklamowano na przykład tymi słowami:

Der Stoff dieses rührenden Stïcks, der sich auf eine wahre Geschichte grïndet, konnte unter den Meisterhänden eines Leßings nicht anders als unvergleichlich gerathen, nur dieser scharfsinnige Geist warfähig, der Bahn des Shackespear so glïcklich zu folgen. Liebhabern der schönen Wissenschaften kann es nicht unbekannt seyn, wie sehr diese Piece in allen Journalen erhoben worden, und wie es durch wiederholte Vorstellungen auf einigen der berïhmtesten Bühnen immer ein neues Glück behauptet ${ }^{56}$.

Były to również komentarze krótkie i żartobliwe, jak ten do utworu pt. Der glückliche Einfall: „Dieses Lustspiel nehmen wir auf unsere Rechnung, es muß gefallen; und wir wünschen guten Appetit". Chcąc pozyskać przychylność publiczności, w komentarzu wartość sztuki podkreślano uznaniem zdobytym już przez nią w innych miastach europejskich. Był to jeden z popularniejszych motywów wykorzystywanych $\mathrm{w}$ tej rubryce. Czasami raz przyjęty na afiszu komentarz nie opuszczał go przez długie lata. Taki sam bowiem, znajdujący się na afiszach Lanassy z 1782 roku, odnajdujemy jeszcze w drugiej połowie lat dziewięćdziesiątych:

\footnotetext{
${ }^{53}$ Egz. BG PAN, sygn. Od $214852^{\circ} ; 27$ in Oe $568^{\circ}$.

${ }^{54}$ Por. H. Widacka, Gdanisk w rycinach Mateusza Deischa, „Rocznik Gdański” t. 50, 1990, z. 1, s. 211.

${ }^{55} \mathrm{~W}$ niniejszym artykule przedstawiono tylko ogólną klasyfikację afiszów, wykorzystując w tym celu nazwę zespołu. Badania, choć nie zostały jeszcze zakończone, pozwoliły uszczególowić ten podział. Na podstawie typografii druków, życiorysów aktorów, których nazwiska widnieją na afiszach, oraz wiadomości z recenzji i zbiorczych repertuarów, udało się w wielu przypadkach ustalić dokładną datę zapowiadanego przez afisz przedstawienia.

${ }^{56}$ Taki sam komentarz powtórzono jeszcze na afiszach utworu Lessinga w 1779 i 1781 roku.
} 
Der Werth dieses vortreflichen Stücks, ist schon nach dem Namen la Veuve du Malabar hinlänglich entschieden. In Berlin ist seit vielen Jahren kein Stück mit allgemeinern Beyfall aufgenommen, als dieses: Franzosen und Deutsche die es daselbst gesehen haben versichern, daß die Deutsche Lanassa einen Vorzug vor dem französischen Original habe. - Es ist in Berlin 25 mahl in kurzer Zeit aufgeführet.

Jednak w latach dziewięćdziesiątych komentarz będzie już rzadkością. Jego miejsce zajęły rubryki zawierające informacje porządkowe i organizacyjne. Najstarszą taką wiadomość, pomijając tu adres teatru, odnaleźliśmy na afiszu Konrada Ernesta Ackermanna z lat pięćdziesiątych: „Die Herrschaftlichen Bedienten werden ohne Eingeld nicht eingelassen”. Nieco inną, a potwierdzająca chyba zwyczaj zasiadania publiczności na scenie w trakcie spektaklu, jest ta oto informacja $\mathrm{z}$ afisza z 1771 roku: „Aufs Theater wird Niemand gelassen”. Wiadomości z późniejszego okresu z reguły dotyczą wskazania miejsc zamawiania biletów i abonowania lóż. W roku 1779 donoszono:

Wer eine aparte Loge verlanget, kostet einen Ducat, und muß selbige Vormittags bey Madam Schuch besellen, logirt bey dem Lackenhändler durchs Glocken-Thor kommende an der Ecke, wo man zugleich den Schlüssel darzu bekommt.

Jedną z najbardziej nietrwałych rubryk było streszczenie, czasami łączone z komentarzem. Pojawia się na niewielu afiszach. Jednym z nich jest anons z 1733 roku znany jedynie $z$ tekstu ${ }^{57}$. Streszczono w nim dwie sztuki: Der großmüthige Siroë, oder: Die triumphirende Gerechtigkeit und von Himmel beschützte Unschuld oraz poprzedzający ten utwór muzyczny prolog w konwencji alegoryczno-mitologicznej Die wiederhergestellte güldne Zeit. Pierwszy z wymienionych utworów był adaptacja wczesnooświeceniowego melodramatu Pietro Metastasia Il Siroe. Do lat osiemdziesiątych streszczano co najwyżej utwory baletowe. Tej rubryki nie wymagały afisze zapowiadające przedstawienia operowe, ponieważ w wielu przypadkach widzowie mogli nabyć przed wejściem do teatru książeczki z ariami, o czym również można było dowiedzieć się $\mathrm{z}$ afisza.

Wspomniany anons z 1733 roku ujawnia autora sztuki pt. Die kostbahren Lächerlichkeiten. Był nim Molier. Zachowany materiał pozwala stwierdzić, że początkowo podawano tylko autorów nie-niemieckich. Pierwszym bowiem autorem niemieckojęzycznym wspomnianym na afiszu z 1771 roku był Józef Feliks von Kurz. Kolejne anonse zaczęły już ujawniać nazwiska autorów oryginałów i tłumaczy, kompozytorów oraz choreografów. Natomiast od 1777 roku niemal regułą stało się podawanie obsady. Wcześniej ograniczano się jedynie do spisu bohaterów anonsowanego utworu. Tej rubryce towarzyszyło wskazywanie miejsca akcji, niekiedy wzbogaconego o czas. W latach siedemdziesiątych i osiemdziesiątych była to czasami obszerna rubryka, podająca wiele szczegółów, dziś będąca materiałem pozwalającym

${ }^{57}$ Por. przyp. 5. 
ocenić możliwości inscenizacyjne teatru. W latach dziewięćdziesiątych określenie miejsca akcji będzie już bardzo ogólnikowe, o ile w ogóle je podawano.

$\mathrm{Z}$ tego pobieżnego przeglądu wynika, że gdański afisz pod koniec osiemnastego wieku zaczyna ograniczać się do funkcji informowania. Coraz mniej w nich zachwalania i czczych przechwałek. Nie sposób tutaj nie wspomnieć, że taką tendencję ujawniają również afisze warszawskie i krakowskie, o czym pisali Zbigniew Raszewski i Maciej Szeleta. Nasuwa się w tym momencie także fragment definicji afisza podanej przez Ludwika Adama Dmuszewskiego i Alojzego Fortunata Źółkowskiego w Dykcjonarzyku Teatralnym:

Afisz, kiedy wychodzi na rzecz antrepryzy, prawie zawsze jest niegrzeczny i prostak, donosi, co będzie, i nic więcej; kiedy zaś benefis zwiastuje, nie masz grzecznisia większego, cały w komplementach i uniżonościach ${ }^{58}$.

Oczywiście to żart, bo to afisze wydawane na rzecz antrepryzy uchodziły wówczas za wyraz dobrego gustu. Przekonuja nas o tym artykuły zamieszczone w gotajskich kalendarzach teatralnych ${ }^{59}$.

W Theater-Kalender na rok 1780 i 1791 anonimowi autorzy narzekali na stan ówczesnych afiszów. Według nich zgorszeniem dla każdego miłośnika teatru były anonse zredagowane $z$ błędami i w tonie mowy pochwalnej, zniżające się tym samym do chełpliwości jarmarcznej budy. Winą za taki stan obarczali nasi autorzy pryncypałów teatralnych, którzy nie tylko czynili z afiszów kadzielnicę obietnic, ale także świadków swojej najbardziej płaszczącej się pokory, zaś auri sacra fames nie mogła nic i nikogo usprawiedliwić. Podano również elementy, które afisz powinien zawierać. Dla pierwszego z autorów dobrze zredagowany anons musiał podawać: dzień i miejsce przedstawienia, tytuł sztuki i jej autora (o ile jest on na pewno znany), obsadę oraz ceny miejsc. Nieco inne obligatoryjne elementy podano w drugim artykule, gdzie za konieczne uznano wskazanie na afiszu: daty przedstawienia, tytułu utworu, jego autora lub adaptatora, występujących postaci, miejsca akcji oraz godziny rozpoczęcia przedstawienia. Jako fakultatywnie mogły natomiast być umieszczane nazwiska aktorów oraz uwagi o zachodzących zmianach scenografii. Wszystkie inne elementy uznano wręcz za złe. Żadnych przechwałek, pochwał, tylko rzeczowe informacje.

Różnice między propozycjami z obu artykułów są zauważalne. W tym drugim nie przyjmuje się za konieczne podawania nazwisk aktorów, a za szkodliwe wskazanie miejsca przedstawienia czy cennik, skoro takie elementy nie zostały wymienione. Natomiast w pierwszym artykule uderza brak podania godziny rozpoczęcia spektaklu. Rozbieżności wskazują zatem na słabość normatywnych ustaleń lub początek ich krystalizowania się. I tu dodajmy, iż na

${ }^{58}$ [L. A. Dmuszewski, A. F. Żółkowski], Dykcjonarzyk Teatralny z dodatkiem pieśni z najnowszych oper dawanych na Teatrze Narodowym Warszawskim, Poznań 1808, s. 9.

${ }^{59}$ Zob. Theater-Kalender, auf das Jahr 1780, Gotha [1779], s. 7-9. Egz. Biblioteki Instytutu Sztuki w Warszawie, sygn. P I 90; Theater-Kalender, auf das Jahr 1791, Gotha [1790], s. 71-76. Egz. Biblioteki Narodowej w Warszawie, sygn. P.S. 550. 
obszarze ówczesnej Polski w XVIII wieku żadna z tych reguł nie przyjęła się bezwarunkowo, również w Gdańsku. Dotyczy to także afiszów z obszaru niemieckojęzycznego, co potwierdziły badania Johanna Hänsela ${ }^{60}$. Niemniej skromność afisza stała się pod koniec tegoż stulecia zaletą, nie wadą, świadczyła o dobrym smaku.

O poprawę wizerunku afisza występowano również w Gdańsku i to znacznie wcześniej. W 1769 pojawiły się dwa pisma omawiające gdańskie występy zespołu Karola Teofila Döbbelina $z$ poprzedniego roku ${ }^{61}$. Anonimowy autor jednej z tych prac czuł się urażony $z$ powodu uwag zamieszczonych na afiszach przez bawiącego tu pryncypała trupy. W złym guście według niego - było na przykład specjalne polecanie uwadze widzów nowych członków zespołu - pana i panią Garbrecht, którzy odtwarzali postaci Barona von Altholz i Baronową, "ein Paar alten, abgelebten, widerlichen und ganz invaliden Theater-Helden” w sztuce Die Heyrath durch Wechselbriefe ${ }^{62}$. Podobnych bardzo subiektywnych i nieco złośliwych ocen znaleźlibyśmy w tej recenzji więcej ${ }^{63}$. Nie można odmówić jednak racji naszemu krytykowi, gdy oburzał się z powodu oznaczenia na afiszu jako premiery drugiego przedstawienia sztuki zatytułowanej Die neue Agnese Löwena (26 sierpnia, premiera 20 sierpnia) ${ }^{64}$.

Afiszem interesowali się nie tylko widzowie czy krytycy, ale także Rada Miasta. To ona w 1759 roku wydała przepisy regulujące działalność oficyn wydawniczych nad Motławą ${ }^{65}$. W myśl artykułu VII między innymi afisze miały być drukowane przez osoby, które posiadały tytuł Senatus et Athenaei Typographus. Były one również zobowiązane do zagwarantowania staranności wydania i możliwości druku w wielu językach. Obecnie nie możemy jednak stwierdzić, że wszystkie osiemnastowieczne afisze gdańskie wyszły spod prasy drukarza miejskiego i gimnazjalnego. Według opinii znawczyni gdańskiego drukarstwa, Marii Pelczarowej, nadmotławskie afisze zespołu baletowego Le Deux z 1804 roku, podobnie jak afisze zespołów niemieckich z wcześniejszego okresu, były drukowane w oficynie Jana Emanuela Müllera juniora ${ }^{66}$. Jednak właściciele tego warsztatu nie nosili w XVIII wieku tytułu Senatus et Athenaei Typographus. Była to druga oficyna działająca nad Motławą obok drukarni Rady i Gimnazjum ${ }^{67}$. Z kolei Zbigniew Nowak uważa, że między tymi zakładami nie było wyraź-

${ }^{60}$ Zob. J. R. Hänsel, op. cit. , s. 177-229.

${ }^{61}$ Ueber die Döbbelinische Schauspielergesellschaft. Ein Brief an einen Freund in Königsberg, [Danzig] 1769. Egz. BG PAN, sygn. Uph. o. 4832; Gedanken über den Brief des Herrn S. die Döbbelinische Schauspielergesellschaft betreffend, [Danzig] 1769. Egz. BG PAN, sygn. Uph. o. 4832.

${ }^{62}$ Gdanken über den Brief..., op. cit., s. 51-52.

${ }^{63}$ Autorowi chodzilo głównie o zdyskredytowanie w oczach gdańszczan zespołu Döbbelina, aby tym samym podnieść rangę krytykowanej we wcześniejszym piśmie (Ueber die Döbbelinische..., op. cit. ) konkurencyjnej trupy Franciszka Schucha Młodszego.

${ }^{64}$ Gedanken über den Brief..., op. cit., s. 55-56.

${ }^{65}$ Es. Rahts aufs neue ïbersehene und vermehrte Buchdrucker-Ordnung, Danzig 1759. Egz. BG PAN, sygn. Od 5711

$8^{\circ}$ adl. 107; por. E. Kotarski, op. cit., s. 24-26.

${ }^{66}$ Zob. Z. Ciesielski, A. Świderska, op. cit., s. 459

${ }^{67} \mathrm{Na}$ temat drukarń i drukarzy w osiemnastowiecznym Gdańsku por:: Drukarze dawnej Polski od XV do XVIII wieku, t. 4: Pomorze, opr. A. Kawecka-Gryczowa, K. Korotajowa, Wrocław 1962; M. Pelczarowa, Z dziejów oficyn drukarskich w Gdańsku (w. XVI-XVIII), „Rocznik Gdański” t. 14, 1955, s. 144-165; Z. Nowak, Gdańsk 
nego i respektowanego podziału ról ${ }^{68}$, co pozwala wnioskować, iż w osiemnastowiecznym Gdańsku działały zasady wolnego rynku, a rozporządzenia Rady Miejskiej mogły być nierespektowane. Sam fakt wydania takiej ordynacji może o tym świadczyć.

Rada Miejska nie tylko zabierała głos we wspomnianym edykcie na temat podziału ról między drukarniami. Ustanawiała również cenzurę. Artykuł XXIV zobowiązywał drukarzy do przedstawiania i zatwierdzania przez sekretarza archiwum miejskiego między innymi afiszów teatralnych. Warto natomiast zapytać, na ile to rozporządzenie było skuteczne i w jakim stopniu przestrzegane. Nie można tu generalizować, ale niektóre anonse teatralne były chyba grą z cenzurą, czego przykładem wydaje się afisz gdańskiej premiery Zbójców Schillera z 1786 roku $^{69}$. Dwa lata wcześniej Rada Miasta uznała tę sztukę za niemoralną i zabroniła Joannie Karolinie Schuch jej wystawienia. O ile ówczesny gdańszczanin mógł nie znać zakulisowych poczynań zespołu z Radą Miasta, nie dotrzeć do wydania sztuki czy do Taschenbuch für die Schaubiihne ${ }^{70}$ lub do berlińskiego czasopisma „Litteratur- und Theater-Zeitung" z końca 1784 roku, w którym opisano całe zajście ${ }^{71}$, o tyle mógł się dowiedzieć z ówczesnego afisza lub przynajmniej domyśleć się, co było powodem pierwotnego odrzucenia sztuki Schillera przez Radę Miasta. Natomiast w 1786 roku na gdańskiej scenie nie posłużono się oryginałem utworu, ani — jak zamierzano dwa lata wcześniej — mannheimską adaptac$\mathrm{ja}^{72}$, lecz przeróbką autorstwa Karla Martina Plümickego, którą w afiszu tak skomentowano:

Herr Plïmicke hat dieses Stück für die Berliner Bühne bearbeitet: indem es ihm unnatïrlich schien, daß ein Sohn so äußerst grausam an seinem Vater handeln könne. Er machte also den Franz Moor zum Bastard.

Zaznaczono przy tym, iż ocenę prezentowanej adaptacji pozostawia się „życzliwej publiczności". Zespół tym afiszowym komentarzem nie tylko dawał do zrozumienia gdańszczanom, czym oryginał różnił się od przeróbki, ale uwalniał się niejako od odpowiedzialności za treść prezentowanej sztuki.

jako ośrodek drukarski i wydawniczy do końca XVIII wieku, „Rocznik Gdański” t. 50, 1990, z. 1, s. 129-151.

${ }_{68}$ Zob. Z. Nowak, Zmierzch siwietności gdańskiej kultury w latach 1793-1814, w: Historia Gdańska, t. 3, cz. 2: 1793-1815, red. E. Cieślak, Gdańsk 1993, s. 214.

${ }^{69}$ Dotychczas przyjęło się podawać rok 1785 jako czas gdańskiej premiery Zbójców - zgodnie zresztą $\mathrm{z}$ rękopiśmienną adnotacją na afiszu. W odnalezionym źródle (wspomniana wcześniej kronika Rubacha, egz. BG PAN, sygn. 149, k. 61 v. ) podano natomiast datę późniejszą: 23 listopada 1786 . W oryginale cały ten fragment brzmi: „1786. Novemb[er] 23. [Donnerstag] und Freytag als den 24sten wurde das Schillerische Stïck Die Räuber nach Pliimickens Veränderungen, welches schon vor 2 Jahr hier gegeben werden sollen, aber wegen verschiedenes Hinderungen so lang unterbleiben mußte, zuerst hier aufgefihhret".

${ }^{70}$ Taschenbuch für die Schaubühne, auf das Jahr 1785, Gotha [1784], s. 225. Egz. BG PAN, sygn. Kab $10328^{\circ}$.

${ }^{11}$ Eins und das andere ïber die Schuchische Gesellschaft bey ihrem Aufenthalt in Danzig 1784, "Litteratur-und Theater-Zeitung" 1784, nr 45, s. 90-91. Egz. BUW, sygn. 019151.

${ }^{72} \mathrm{O}$ mannheimskiej przeróbce, a nie o adaptacji dokonanej przez Plümickego, pisano w „Litteratur-und Theater-Zeitung" (por. przyp. 71). 
Przedstawiony tutaj materiał to tylko wybrane problemy, które wiążą się z lekturą gdańskich afiszów. Szersze, bardziej szczegółowe badania, które są prowadzone, z pewnością przyniosą jeszcze wiele nowych ustaleń, sprecyzują zagadnienia zaledwie tu poruszane. O innych, jak na przykład o typografii tych druków, nie było tu mowy. Nie sposób nie powiedzieć w tym miejscu, jak ważnym źródłem są afisze do badań nad dziejami gdańskiej sceny. Niekiedy są one jedynym zachowanym dowodem obecności danego zespołu czy aktora nad Motławą. Dość wspomnieć, że o gdańskich występach zespołu Józefa Nowickiego w 1793 roku było dotychczas wiadomo tylko dzięki takiemu drukowi, niestety, znanemu dziś jedynie $z$ tekstu ${ }^{73}$. Afisze te mogą być także wykorzystywane do badań nad dziejami innych ośrodków teatralnych. Odnajdujemy tu wszak nazwiska osób, które występowały na wielu europejskich scenach: w Berlinie, Petersburgu, Wiedniu, Warszawie, Szczecinie, Rydze, Dreźnie. O przyjazdach czy gościnnych występach również informował afisz. Osoby te miały także wpływ na dobór repertuaru. Wraz z przybyciem z Berlina w 1779 roku Siegfrieda Gotthilfa Kocha (właśc. Eckhardt) zaczęto wystawiać Hamleta, w którym odtwarzał on tytułową postać z wielkim powodzeniem ${ }^{74}$. Później - w 1819 roku - to on wcielił się w Natana w wiedeńskiej premierze dramatu Lessinga Natan mędrzec ${ }^{75}$. Przecież kontakt Gdańska z pozostałymi obszarami Polski nie ograniczał się do występów Nowickiego i Truskolaskich. Tu w Gdańsku odnajdujemy afisze znanych ze swej działalności w Polsce włoskich operzystów: Domenico Toniolego, Rosę Scanavini i jej córkę - Celestinę. Również ze sceną warszawską związani byli tacy aktorzy, jak: Konrad Ernest Ackermann, Franz Barzanti, Joseph Bodenburg, Czike, Gottlieb Friedrich Lorenz, by nie wspomnieć Kurza.

Zbigniew Raszewski pisał, że „Afisza XVIII wieku właściwie nie można sobie wyobrazić bez bujnego komentarza (...)"76. Trudno również sobie obecnie wyobrazić pisanie historii scen wielu miejscowości bez sięgnięcia do gdańskich teatraliów, w tym także do zachowanego zbioru nadmotławskich afiszów.

\footnotetext{
${ }^{73}$ Por: S. Dąbrowski, Pienwsze występy aktorów warszawskich $w$ Gdańsku w r. 1793, w: idem, Aktorowie w podróży, wst. Z. Raszewski, Warszawa 1969, s. 15-16; Z. Raszewski, Z tradycji..., op. cit., s. 66-69. Obecnie możemy wzbogacić naszą wiedzę na temat wizyty Nowickiego w Gdańsku dzięki odnalezionej w prasie notatce: „Mit Bewilligung einer hohen Obrigkeit, wird Herr Joseph Nowicky mit seiner hier angelangten Gesellschaft Polnischer Schauspieler, nächsten Donnerstag, den 3. Januar, im hiesigen Schauspielhause die Erste Vorstellung geben. Ein Näheres wird durch die auszutheilenden Zettel bekant gemacht werden. Billette zu den Logen und Parterre sind bei Hrn. Nowicki, am Vorstädtschen Graben im Hause des Kornmessers Stobbe, zu haben” („Deutsche Zeitung” 1792, nr 156, k. 2 v. Egz. BG PAN, sygn. Uph. q. 2428).

${ }^{74}$ Szerzej o szekspirowskich przedstawieniach z udziałem S. G. Kocha por. P. Kąkol, Trzy premiery i stary utwór, czyli Szekspir na gdańskiej scenie w XVIII wieku, „Studia Bałtyckie” 8, Polonistyka t. 1, 1998, s. 163-200.

${ }^{75}$ Zob. O. Dobijanka, wstęp do: G. E. Lessing, Natan mędrzec. Poemat dramatyczny w pięciu aktach, ti. A. Szczerbowski, Wrocław 1963 (BN II 140), s. XII, XVI.

${ }^{76}$ Z. Raszewski, Warszawski afisz..., op. cit., s. 528.
} 